\title{
GENE FREQUENCIES IN ICELANDIC CATS
}

\author{
NEIL B. TODD \\ Cornivore Genetics Research Center, P.O. Box 5, Newtonville, Mossachusetts 02160 \\ ROBERT M. FAGEN \\ Division of Engineering and Applied Physics, Harvard University, Cambridge, Massachuse tts \\ and \\ KAREN FAGEN \\ Department of Psychology, New York University
}

Received 19.x.74

\begin{abstract}
SUMMARY
A survey of genetically determined coat polymorphisms of Icelandic cats, in Reykjavik and adjacent rural areas, has shown that these animals are quite distinct from cats previously studied in north-west Europe. The differences are interpreted to indicate that Icelandic cats represent a relict population reflecting the condition of north-west European cats in former times.

Significant differences exist between the Reykjavik and rural samples studied. The Reykjavik population is more similar to north-west Europe, probably due largely to increased contact in recent years.
\end{abstract}

\section{INTRODUCTION}

Felis catus, both the domestic form and various wild races, is a species indigenous to the Old World including much of Europe, Asia and North Africa. It is now endemic in the New World, Africa south of the Sahara, Oceania and many islands around the globe. In general, the transportation of cats into these latter areas has coincided with European exploration and expansion over the last three or four centuries. Most of the colonial populations of cats were drawn directly from the European countries originally active in a given overseas region. Once such populations became established, later political changes have had little impact on their nature.

Cat gene frequencies have now been determined in many places around the world (table 1). The findings have revealed a number of large areas in which mutant frequencies are relatively homogeneous, in particular in north-west Europe, eastern North America and Australia. Other regions that may yet prove to be more or less discrete are central Europe, southeast Europe, the Iberian peninsula, etc., but definitive data are not yet available.

Thus far attention has been focused on two basic problems: (1) the interrelationships of various European populations and (2) the relationships between European populations and their respective colonial derivatives. The first problem seems to be reaching resolution through the description of additional areas. Most loci studied show either widespread homogeneity or fairly regular clines. As further information accumulates it seems reasonable to suppose that a detailed and accurate interpretation of at least the recent genetic history of cats in Europe will be possible.

The second problem, that concerning the relationship between European and colonial groups, is certainly more complex. A straightforward comparison reveals some sharp disparities between present European values and 
those in derivative populations. While it might be argued that the relative isolation of colonial populations for centuries has led to local modification through drift or selection, no clear evidence of this has been found. It seems that cat populations are usually large enough to be more or less refractory to random genetic change and in so far as selection is concerned, mutant frequencies must be little affected by what may be called geophysical or climatological factors (see, for example, Dreux and Todd,

TABLE 1

Mutant gene frequencies in some European and European derived populations of cats

\begin{tabular}{|c|c|c|c|c|c|c|c|c|}
\hline & 0 & $a$ & $t^{b}$ & $d$ & $l$ & $S$ & $W$ & Reference \\
\hline Cyprus & $0 \cdot 21$ & 0.72 & $0 \cdot 25$ & 0.35 & 0.50 & $0 \cdot 34$ & 0.001 & Robinson, 1972 \\
\hline Chios & $0 \cdot 20$ & $0 \cdot 70$ & $0 \cdot 23$ & $0 \cdot 28$ & $0 \cdot 13$ & $0 \cdot 36$ & $0 \cdot 00$ & Todd et al., 1974 \\
\hline Athens & $0 \cdot 13$ & $0 \cdot 72$ & $0 \cdot 26$ & $0 \cdot 34$ & $0 \cdot 13$ & $0 \cdot 27$ & 0.009 & Todd et al., 1974 \\
\hline Argolis & $0 \cdot 18$ & 0.74 & $0 \cdot 18$ & $0 \cdot 20$ & $0 \cdot 00-$ & $0 \cdot 23$ & $0.00-$ & Todd et al., 1974 \\
\hline Vienna & $0 \cdot 10$ & 0.57 & $0 \cdot 29$ & $0 \cdot 22$ & - & $0 \cdot 17$ & 0.001 & Baxa, 1973 \\
\hline Venice & 0.06 & 0.58 & 0.48 & 0.35 & - & $0 \cdot 27$ & 0.007 & Searle, 1966 \\
\hline Rome & 0.07 & 0.65 & 0.47 & 0.32 & - & - & 0.02 & Dyte, pers. comm. \\
\hline Chamonix & $0 \cdot 10$ & 0.75 & $0 \cdot 69$ & 0.40 & $0 \cdot 32$ & $0 \cdot 22$ & 0.014 & Dreux, 1971 \\
\hline Marseille & 0.06 & $0 \cdot 70$ & $0 \cdot 69$ & $0 \cdot 30$ & $0 \cdot 28$ & - & 0.02 & Dreux, $1969 a$ \\
\hline Paris & 0.06 & $0 \cdot 71$ & 0.78 & 0.33 & 0.24 & $0 \cdot 24$ & 0.011 & Dreux, 1967 \\
\hline Mayenne & $0 \cdot 15$ & $0 \cdot 64$ & $0 \cdot 61$ & $0 \cdot 29$ & $0 \cdot 17$ & $0 \cdot 39$ & 0.006 & Dreux, 1968 \\
\hline The Hague & $0 \cdot 21$ & $0 \cdot 65$ & $0 \cdot 66$ & $0 \cdot 26$ & $0 \cdot 16$ & $0 \cdot 36$ & 0.02 & Dreux and Legel, 1973 \\
\hline Southern England & $0 \cdot 19$ & $0 \cdot 80$ & $0 \cdot 84$ & $0 \cdot 26$ & $0 \cdot 31$ & 0.38 & 0.01 & Robinson and Silson, 1969 \\
\hline London & $0 \cdot 11$ & $0 \cdot 76$ & $0 \cdot 81$ & $0 \cdot 14$ & 0.33 & $0 \cdot 37$ & 0.004 & Searle, 1949 \\
\hline York & $0 \cdot 20$ & $0 \cdot 81$ & $0 \cdot 78$ & $0 \cdot 27$ & - & $0 \cdot 33$ & 0.01 & Metcalfe and Turner, 1971 \\
\hline Reykjavik & $0 \cdot 13$ & $0-60$ & 0.53 & 0.44 & $0 \cdot 14$ & 0.49 & 0.01 & This paper \\
\hline Iceland-rural & $0 \cdot 20$ & $0 \cdot 64$ & $0 \cdot 30$ & 0.34 & $0 \cdot 10$ & 0.44 & $0 \cdot 06$ & This paper \\
\hline Boston & $0 \cdot 19$ & $0 \cdot 64$ & $0 \cdot 44$ & $0 \cdot 43$ & $0 \cdot 30$ & 0.44 & 0.022 & Todd, $1964 b$ \\
\hline New York & $0 \cdot 14$ & 0.75 & 0.47 & 0.44 & $0 \cdot 13$ & 0.47 & 0.013 & Todd, 1966 \\
\hline Philadelphia & $0 \cdot 26$ & $0 \cdot 70$ & $0 \cdot 45$ & 0.48 & $0 \cdot 18$ & 0.42 & 0.012 & Todd, 1969 \\
\hline Columbus & $0 \cdot 29$ & 0.64 & $0 \cdot 31$ & 0.50 & - & 0.43 & 0.01 & Tinney and Griesemer, 1968 \\
\hline Chicago & $0 \cdot 22$ & 0.71 & $0 \cdot 34$ & $0 \cdot 45$ & $0 \cdot 37$ & $0 \cdot 31$ & 0.02 & Todd, 1969 \\
\hline Bloemfontein & 0.08 & 0.78 & 0.48 & $0 \cdot 49$ & $0 \cdot 13$ & - & 0.02 & Dreux, $1969 b$ \\
\hline Adelaide & $0 \cdot 19$ & 0.78 & $0 \cdot 71$ & $0 \cdot 33$ & $0 \cdot 38$ & $0 \cdot 29$ & 0.023 & Clark, 1973 \\
\hline Brisbane & $0 \cdot 14$ & 0.81 & $0 \cdot 68$ & 0.45 & - & 0.41 & 0.022 & Moffatt, 1968 \\
\hline Melbourne & $0 \cdot 14$ & $0 \cdot 85$ & $0 \cdot 61$ & $0 \cdot 47$ & - & $0 \cdot 21$ & 0.039 & Moffatt, 1968 \\
\hline Hobart & $0 \cdot 22$ & $0-76$ & $0 \cdot 81$ & $0 \cdot 25$ & 0.46 & $0 \cdot 39$ & 0.04 & Dartnall, 1974. \\
\hline Dunedin & $0 \cdot 20$ & $0 \cdot 81$ & $0 \cdot 87$ & $0 \cdot 30$ & 0.47 & $0 \cdot 22$ & 0.036 & Marples, 1967 \\
\hline
\end{tabular}

1974). Hence, some other explanation must be sought to explain the differences that have been noted. One proposition holds that present colonial frequencies approximate those of Europe at the time animals were first exported and that European frequencies have changed over the last few centuries (Todd, 1969). A certain amount of evidence can be mustered in support of this.

The colonial populations of eastern North America, South Africa, Australia and New Zealand may be taken to represent European samples of the early and mid-seventeenth century, late eighteenth century and midnineteenth century, respectively. By plotting time against allele frequencies, a time-course of change can be suggested. For some loci, the supposed trends predict quite well the mid-twentieth century north-west European values (fig. 1).

Further support rests on the fact that the selection acting to bring about these changes correlates with what may be described as a rural-urban 
factor. That is, rural populations (assumed to approximate historically pre-urban conditions in many respects) display frequencies for certain alleles which in urban situations are modified. The overall effect of these spatial changes are the same as the temporal changes postulated for north-west Europe. The actual status of a given population is presumed to be determined by what may be called "cumulative urban pressure" which is the net result of the interplay of historically recent and remote ecological

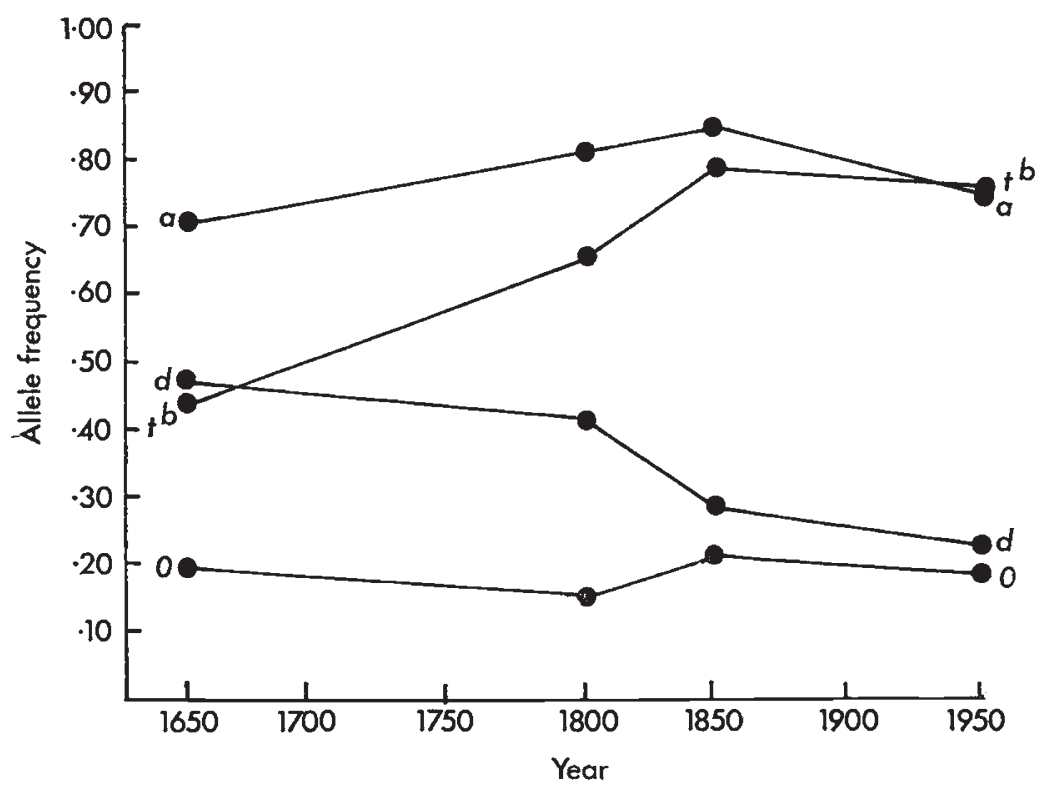

Fig. 1.-Approximate time course of allele frequency changes in north-west Europe. Estimated past values were derived by simple averaging (without regard to sample size) as follows: 1650-Bloemfontein, Boston, New York City, Philadelphia and Columbus, Ohio; 1800-Brisbane, Melbourne and Adelaide; 1850-Dunedin and Hobart; 1950The Hague, South England, London and York.

conditions. The selection pressure(s) operating, whatever they may be, tend to favour darker phenotypes or higher frequencies of darker phenotypes. A given population may be scaled by use of the "coefficient of darkness" which is the theoretical frequency in a population of the two darkest male phenotypes. This has been discussed in detail elsewhere (Todd, 1969).

The present census of cats in Iceland was conceived to provide data ostensibly based on a sample drawn from north-west Europe at a much earlier time than the populations heretofore investigated. In order to analyse the results of the present survey, it is necessary to discuss the events surrounding the inception of the cat population of Iceland. This, in turn, requires reviewing certain general and historical facts concerning Great Britain, Ireland and northern Scandinavia.

Since the Pleistocene glacial retreat, the areas now known as Scotland, Wales and England were well populated by so-called Felis sylvestris, the European wild cat. On the Continent, this form was probably also established as far north as Denmark. Today, except in the more remote parts 
of the Highlands of Scotland, this animal has disappeared, apparently the victim of persecution by man and competition with the domestic race, or absorption through interbreeding. In northern Scandinavia, no cats are known before the introduction of the domestic form.

The earliest evidence of domestication of the cat in north-west Europe is found in Roman Britain (Jones, 1906) in the fourth century A.D. This does not, of course, preclude prior domestication which is quite probable, but there is no evidence of it. The arrival of the domestic cat in Ireland could hardly have occurred before its inception in Roman Britain, but by the fifth and sixth centuries, when Celtic raids on Roman settlements became common, its transportation to Ireland must have taken place. Therefore, by the time Viking incursions into Ireland began in the late eighth century, Irish cat populations were probably firmly established. It might be mentioned, incidentally, that the arrival of the domestic cat in Ireland constituted a different situation from what had previously taken place. In all other areas the domestic race would unavoidably have been in intimate contact with the wild race. The presence of a wild reservoir would tend to retard genetic responses in the domestic population. It is, therefore, possible that the effects of any selection pressures associated with domesticity might have been more pronounced in Ireland than in Great Britain. This would eventually be true in northern Scandinavia and, ultimately, in Iceland.

When the Norse Vikings began their expansion, their first important and sustained contact with cats of any kind may have been with the domestic form in Ireland (c. A.D. 800), and perhaps with the domestic and wild races in northern Scotland. Thus, it is not improbable that the first cats to reach northern Scandinavia were part of Viking booty brought from Ireland. At the same time, the Faeroes and islands north of Scotland must also have been "seeded" with cats in limited numbers. The origin of southern Scandinavian cats appears to be a separate problem, since wild Felis may have inhabited Denmark, and since contact with France and other areas could possibly have resulted in the movement of cats during the period in question (Jones, 1973).

Given the foregoing considerations, it seems likely that when cats finally reached Iceland, they were drawn directly or indirectly from Ireland, with possible admixture of wild influences from Scotland. Moving back one stage earlier leads to a source from Roman Britain. These latter animals would be largely descendants of the wild race, perhaps interbred with a few imported domestic animals which served as a catalyst in the domestication process. Hence, a case can be made for assuming that Icelandic cats are derived from a ninth-century, if not earlier, north-west European population that may be compared with other samples of later date. The possibility that the original "propagule" was biased is rejected on the basis of the historical record. This record leaves no doubt that the wave of human migration to Iceland and population growth between A.D. 874 and A.D. 925 established over 20,000 people (Bjarnason et al., 1973). Under these circumstances it is improbable that founder effect could have played an important role.

The genetic factors assessed in this study comprise sex-linked non-orange, orange $\left(\mathrm{O}^{+}, \mathrm{O}\right)$ and the autosomal (and apparently independent) loci controlling agouti, non-agouti $\left(a^{+}, a\right)$; Abyssinian, striped and blotched 
tabby $\left(T^{a}, t^{+}, t^{b}\right)$; non-dilute, dilute $\left(d^{+}, d\right)$; short hair, long hair $\left(l^{+}, l\right)$; dominant piebald spotting, non-spotted $\left(S, s^{+}\right)$; dominant white, pigmented $\left(W, w^{+}\right)$; silver, non-silver $\left(I, i^{+}\right)$; and Manx tailless, normal tail $\left(M, m^{+}\right)$. A comprehensive review of the formal genetics of these mutants can be found in Robinson (1971). Calculation of gene frequencies for these systems has been discussed in detail in many previous papers and need not be repeated here.

\section{Results}

The data collected in Iceland to date have come from two sources that are geographically and ecologically distinguishable from one another. The first is Reykjavik and immediate vicinity; the second is a belt not more

TABLE 2

The distribution of non-orange $(+/+,+/-)$, tortoiseshell $(+\mid O)$ and orange $(O / O, O /-)$ phenotypes in Reykjavik and adjacent rural areas

\begin{tabular}{lccccccc} 
& & $+1+$ & +10 & $0 / O$ & $+1-$ & $0 /-$ & \\
Reykjavik & & 33 & 15 & 0 & 47 & 5 & \\
\multirow{2}{*}{ alleles } & + & 66 & 15 & - & 47 & - & \\
Rural & $O$ & - & 15 & 0 & - & 5 & $q O=0.135 \pm 0.028$ \\
& & 21 & 10 & 1 & 27 & 8 & \\
alleles & + & 42 & 10 & - & 27 & - & \\
& $O$ & - & 10 & 2 & - & 8 & $q O=0.202 \pm 0.036$
\end{tabular}

distant than some $50 \mathrm{~km}$ from Reykjavik consisting of rural and village sites. The animals in the first sample comprised some destroyed as unwanted as well as household pets seen alive. The animals in the second sample were seen principally on farms where they live either as household or barn pets and on the streets and in gardens in small towns and villages. The first sample numbered 104 cats; the second sample 91 cats. Both groups were selected from larger numbers in order to assure the scoring of only one individual from known or suspected related animals.

The observed and predicted frequencies of the phenotypes (non-orange, tortoiseshell and orange) controlled by the sex-linked $\mathrm{O}^{+}, \mathrm{O}$ alleles, were compared for correspondence to Hardy-Weinberg equilibrium. These data are presented in table 2 . The Reykjavik fit is poor $\left(\chi^{2}=25 \cdot 21 ; \mathcal{N}=3\right)$ but the rural fit is excellent $\left(\chi^{2}=1.82 ; \mathcal{N}=3\right)$. Such anomalies have been noted before (Dreux and Legel, 1973) and may be due to erratic human selection. This selection, while causing some occasional perturbations, does not appear to have a permanent effect. In this instance there is a paucity of orange phenotypes among the Reykjavik sample. This may reflect nothing more than a preference for orange cats as pets. They would then tend to be absent from a group of unwanted cats. Hence, $O$ may have been underestimated in Reykjavik. On the other hand, animals selected as pets are frequently sterilised by their owners. This, from a genetic point of view, is equivalent to destruction. In any case, the gene frequencies for $O$ in the two samples do not differ significantly $\left(\chi^{2}=1.95\right)$ and, therefore, no special concern is attached to the Reykjavik discrepancy. 
In table 3 are contained the observed phenotypes and gene frequencies for the loci studied in the two Icelandic samples. No Abyssinian tabby or polydactyl cats were seen. Excluding Manx and silver, which appear only in the Reykjavik group, blotched tabby and dominant white are the only alleles that show statistically significant differences. The interpretation of these differences within the Icelandic population will be included in the discussion of differences between Iceland and other regions.

TABLE 3

Phenotype and gene frequencies in cats of Reykjavik and adjacent rural areas

\begin{tabular}{|c|c|c|c|c|}
\hline & \multicolumn{2}{|c|}{ Reykjavik } & \multicolumn{2}{|c|}{ Rural } \\
\hline & Phenotypes & Gene Freq. & Phenotypes & Gene Freq. \\
\hline$O$ & - & $0.135 \pm 0.028$ & - & $0.202 \pm 0.036$ \\
\hline$a$ & $35 / 96$ & $0.604 \pm 0.041$ & $28 / 70$ & $0.632 \pm 0.046$ \\
\hline$t^{b}$ & $19 / 68$ & $0.528 \pm 0.051$ & $5 / 54$ & $0.304 \pm 0.065$ \\
\hline$d$ & $19 / 99$ & $0.438 \pm 0.045$ & $9 / 77$ & $0.342 \pm 0.054$ \\
\hline$l$ & $3 / 104$ & $0 \cdot 170 \pm 0 \cdot 048$ & $1 / 91$ & $0 \cdot 105 \pm 0.052$ \\
\hline$S$ & $26 / 101$ & $0.493 \pm 0.043$ & $25 / 80$ & $0.441 \pm 0.046$ \\
\hline$W$ & $101 / 104$ & $0.015 \pm 0.008$ & $11 / 99$ & $0.062 \pm 0.017$ \\
\hline
\end{tabular}

The two values found for $O$ in Iceland $(0 \cdot 135$ and $0 \cdot 202)$ do not differ appreciably from those in several north-west European populations, especially those of Great Britain and The Hague. Nor do they contrast sharply with north-east North American frequencies, which are taken to be seventeenthcentury derivatives of north-west Europe. It would appear that only in France and south-central Europe is there an area of lower incidence. It has been proposed that $O$ is an allele sensitive to "cumulative urban pressure" with frequencies falling under urban conditions. When related rural and urban areas are compared, this proposition is sustained; e.g. south England $v$. London; Mayenne $v$. Paris; Chios $v$. Athens; and in the present case rural Iceland $v$. Reykjavik. However, there are obviously pre-existing geographic clines that were determined largely before the present pressures evolved and these make direct interregional comparisons difficult.

Non-agouti is almost universally high, but for Europe, highest in Great Britain (0.78-0.81) and lowest in Austria and northern Italy $(0 \cdot 57-0 \cdot 58)$. The low frequency in the latter area may relate to continued contact with the wild race until very recently. On the other hand, both studies (Searle, 1966; Baxa, 1973) were based on stray cats as opposed to owned pets. This may account for some of the differences noted.

Blotched tabby (which might more usefully be called European tabby) is the most informative locus to examine. The frequency in north-west Europe is quite high. For instance, the axis roughly delineated by YorkLondon-Paris (admittedly an intensely urban swath) has a uniformly high frequency of $t^{b}(0 \cdot 78-0 \cdot 84)$. For Reykjavik the frequency is $0 \cdot 53$. Values below this in Europe have thus far been found only south or east of the Alps, although it is not to be construed that these areas served as a source for Icelandic cats. Rather, the 0.53 level of $t^{b}$ is grossly consistent with the hypothesis that a low incidence reflects an early time of derivation from north-west Europe. However, it is not as low as would be expected for the early date of presumed sampling. For instance, 0.53 is somewhat 
higher than levels found on the U.S. north-east coast. A number of possible explanations are available for this apparent discrepancy. In tentative order of importance these are: (1) continual contact between Reykjavik and north-west Europe; (2) recent (1940 onwards) intense contact between Reykjavik and north-west Europe; and (3) recent (postwar) growth and urbanisation of Reykjavik. Each of these effects alone would have the result of closing any gaps between Reykjavik gene frequencies and those of north-west Europe. If the Reykjavik gene frequency was initially lower, it would then be raised. In fact, all three influences have undoubtedly contributed to the present genetic profile of the population.

If the above assumptions are generally valid, then a steep cline for a decreasing frequency of $t^{b}$ should be found moving from Reykjavik to rural Iceland. This is, in fact, shown by the rural frequency of 0.30 which differs significantly $\left(\chi^{2}=6.64\right)$ from the Reykjavik value of 0.53 . It may not be idle to speculate that the rural frequency will be found to drop to even lower levels in more remote places. In any event, the $t^{b}$ frequency may be overestimated for the present rural sample in that several of the blotched tabby cats recorded were seen rather nearer to than farther from Reykjavik, or in towns rather than on farms.

The two frequencies for $d$ dilution, 0.44 (Reykjavik) and 0.34 (rural) do not differ significantly $\left(\chi^{2}=1 \cdot 82\right)$. The mean value of 0.40 is considerably higher than those found in north-west European surveys, most of which show levels below 0.30 , but not unlike north-east North American frequencies which are above $\mathbf{0} \cdot 40$. The similarity of Icelandic and North American values may indicate that $d$ was relatively high for several centuries and has only fallen recently in north-west Europe.

The low frequency for long hair in both Icelandic samples vis-à-vis Europe may ultimately have utility in interpreting the relationship between these two areas. However, the factor is somewhat difficult to assess due to problems in scoring as well as to the fact that many clearly related populations differ considerably in frequencies of $l$.

Piebald white spotting in the two Icelandic samples, 0.49 for Reykjavik and 0.44 for rural Iceland, do not differ significantly from one another. These values are higher than those found in most north-west European populations. They are about the same as those of Boston $(0.436)$, New York (0.471), Philadelphia $(0.421)$ and Columbus, Ohio $(0.430)$, although some U.S. populations are lower (i.e. Chicago, 0.310). The evidence may be interpreted to indicate longstanding higher frequencies in north-west Europe in times past, with reduction only in the last three centuries. The quantity of piebald white spotting exhibited by each cat was scored on a five-point scale (table 4 ) defined by $0=$ spotting absent (or limited to socalled restricted white spotting); $1=$ piebald spotting present over less than 25 per cent of the body surface; $2=25-50$ per cent; $3=50-75$ per cent; 4 = over 75 per cent (excluding dominant white). Whether or not the zero class is included in the analysis, Reykjavik-rural differences in the distribution of the quantity of white spotting as measured by this scale are not significant.

Dominant white requires some special comment. The consensus of opinion is that the frequency of this mutant is determined by an equilibrium set by human selection favouring this phenotype and deleterious pleiotrophic effects which may reduce viability to 0.75 (Robinson, 1970) and selective 
disadvantages. The latter are thought to stem from often associated deafness (Bergsma and Brown, 1971) and/or white colour itself which may interfere with mating, maternal and/or hunting behaviour. However, it can no longer be said that the frequency of dominant white is universally low, for an exceptionally high value has now been found in rural Iceland. This area seems to provide a special environment in which the usual equilibrium is strongly shifted in favour of dominant white. Specifically, most of the dominant white cats recorded were found on dairy farms. Here they often lived in cow barns as pets of children and are routinely provisioned with fresh milk as well as amply supplied with rodents living in forage bins.

TABLE 4

Distribution of piebald white spotting in Reykjavik and adjacent rural cats

$\begin{array}{ccc}\begin{array}{c}\text { Quantity of } \\ \text { piebald spotting }\end{array} & \text { Reykjavik } & \text { Rural } \\ \text { None } & 26 & 25 \\ <25 \% & 15 & 17 \\ 25-50 \% & 28 & 17 \\ 50-75 \% & 28 & 15 \\ >75 \% & 3 & 4 \\ & 100 & 78\end{array}$

One Reykjavik and two rural cats not included in this analysis were piebald, but the amount of spotting was not accurately ascertained.

This combination of sheltering circumstances seems to have provided a non-laboratory setting in which dominant white may rise above the usual 0.02 to 0.03 levels common to free-ranging populations. The 0.06 level recorded in the present sample is, if anything, an underestimate. Other dominant white cats were not included as there was reason to believe they were related to animals that had already been recorded. Nevertheless, the differences between the frequencies in the two samples is significant $\left(\chi^{2}=\right.$ $6 \cdot 18$ ). The fact that the high rural frequency has not had any noticeable impact on Reykjavik (the Reykjavik frequency of $W$ is not as high as some other urban areas), together with other factors, suggests that gene flow between the city and the country is not great. Among these other factors are blotched tabby, discussed above, and the mutants silver and Manx to be considered below.

Silver, a dominant autosomal factor, is difficult to diagnose in the presence of some other mutants, particularly sex-linked orange and nonagouti. Its least equivocal and most spectacular expression is seen in striped and blotched tabbies. In the Reykjavik sample it was possible to identify 12 non-consanguineous animals of the silver phenotype out of a total of 96 cats. It is likely that this is an underestimate due to phenotypic overlapping between normal and silver in the non-agouti class (Turner and Robinson, 1973). Hence, the gene frequency calculated, $p I=0.065 \pm 0.018$, may also be underestimated. In rural areas only one cat out of 80 cats was doubtfully diagnosed as silver, and this animal was seen only some 15 $\mathrm{km}$ south-west of Reykjavik. That other silver phenotypes may have been missed is probable. However, this would be true of both samples and would not much alter the distinction between them. 
Finally, in the Reykjavik sample, three unrelated examples of Manx (tailless) cats were observed. Manx is an autosomal lethal factor (Todd, $1964 a$ ) ; hence the three individuals must have been heterozygotes. Therefore, of 208 loci, three are $M$ and $p M=0.014$. Such a frequency is high for any population other than on the Isle of Man. It is probable that this mutant arose on (or reached) the Isle of Man not before the latter part of the eighteenth century. It has subsequently been strongly favoured by human selection. Given that its incidence in Reykjavik is due to introduction rather than mutation, then such introduction could not have occurred much before the early nineteenth century and, in fact, may have been as late as mid-twentieth century. Again, its apparent absence in adjacent rural areas suggests restricted gene flow out of Reykjavik.

\section{Gonclusions}

All of the differences noted in the two Icelandic populations studied indicate some past restriction of gene flow between them and recent input to Reykjavik from north-west Europe that has yet to be disseminated to the country as a whole. Today, however, this lack of contact must be breaking down as the mobility of Icelanders increases and movement to urban areas takes place. Reykjavik cats today are genetically more similar to north-west European populations than are the rural Icelandic cats sampled. This follows from the evidence supporting recent input to Reykjavik and renders the city unrepresentative of Iceland as a whole. The input may well coincide with the enormous influx of shipping during World War II. The traffic involved was largely from and to eastern North American and British ports, although a significant amount of it was carried in Norwegian merchant ships, hundreds of which escaped the Nazi occupation of Norway (Snyder, 1964).

Because of the foregoing considerations, it is the rural cats of Iceland that must be taken as the least disturbed indicator of the condition of the founding population. On the face of it, these animals do not appear to be much more " antique" than those of north-east North America. However, at least four possible explanations must be taken into account. First, the initial Icelandic immigrant stock must have been derived largely from Ireland, northern Scandinavia and North Atlantic islands. In these places, in the absence of a wild reservoir of cats, mutant alleles favoured by domesticity may have increased at more accelerated rates than in Great Britain and on the Continent. Also, such mutants may have been preferred in cats to be transported in ships. Second, the present sample may have been too close to European contact to reflect the effects of total isolation. More remote Icelandic samples may yield data to clarify this. Third, the entire Icelandic population may have been modified by limited but continual exchange with Europe so that its 1000-year-old origin has been obscured. The net result is a situation that approximates a seventeenth-century northwest European population. Finally, the similarity between Iceland and North America, at least for some factors, may indicate little gene frequency shift for many hundreds of years. In fact, beginning with a hypothetical wild type population, much of the north-west European change seems to have taken place in the last 300 years. If the period between A.D. 1000 and A.D. 1600 was one of relative genetic stability, then it must be assumed 
that a period of rapid genetic change occurred in the first few centuries of domestication.

Acknowledgments.-The authors are very grateful to the National Research Council of Iceland for permission to conduct the survey reported here.

In particular, gratitude is due to Dr Páll A. Pálsson of the Institute for Experimental Pathology, University of Iceland, for his special efforts in securing materials for this study and for the many arrangements made for visiting cat owners. Mr Einar O. Gudmundsson, also of the Institute for Experimental Pathology, is to be thanked for the considerable time and effort expended. Without his guidance and services as interpreter, this work would have been impossible. Finally, the friendly interest and co-operation of the many people visited during the survey must be acknowledged with pleasure and thanks.

\section{RefERENCES}

BAXA, H. 1973. Gene frequencies in stray cat populations from Vienna. Genetica, 44, 25-30.

BERGSMA, D. R., AND BROWN, K. s. 1971. White fur, blue eyes and deafness in the domestic cat. F. Hered., 62, 171-185.

BJARNASON, O., BJARNASON, v., EDWARDS, J. H., FRIDRIKSSON, s., MAGNUSSON, M., MOURANT, A. E., AND tills, D. 1973. The blood groups of Icelanders. Ann. Hum. Genet., 36, 425-458.

Clark, J. M. 1973. Gene frequencies in the domestic cats of Adelaide. Aust. F. Biol. Sci., $26,1215-1219$.

DARTNALl, J. A. 1974. A study of population genetics in the domestic cats of Hobart. Carnivore Genetics Newesl., 2, 212-218.

DREUX, PH. 1967. Gene frequencies in the cat population of Paris. 7. Hered., 58, 89-92. DREUX, PH. 1968. Gene frequencies in the cat population of a French rural district. $\mathcal{J}$. Hered., 59, 37-39.

DREUX, PH. 1969a. Fréquences des gènes chez les chats de Marseille. Carnivore Genetics Nerwsl., 6, 118-120.

DREUX, PH. 1969b. The cats of Kerguelen Island, Réunion and Bloemfontein. Carnivore Genetics Newsl., 7, 170.

DREUX, PH. 1971. Génétique des populations de chats domestiques dans la vallée de Chamonix (Haute-Savoie). Ann. Génét. Sel. Anim., 3, 145-151.

DREUX, PH., AND LEGEL, J. C. 1973. Gene frequencies in the cat population of The Hague (The Netherlands). 7. Hered., 64, 337-339.

DREUX, PH., AND TODD, N. B. 1974. Clinal distribution of the $t^{b}$ and $O$ alleles in European domestic cats. Carnivore Genetics Newsl., 2, 177-180.

JONEs, G. 1973. A History of the Vikings. Oxford University Press, London.

JONES, H. 1906. Cited in Zeuner, F. E. (1963), A History of Domesticated Animals. Harper and Row, New York.

MARPLES, B. J. 1967. Notes on the phenotypes of cats observed in New Zealand and in Thailand. Carnivore Genetics Newsl., 3, 43-44.

METCALFE, J. A., AND TURNER, J. R. G. 1971. Gene frequencies in the domestic cats of York: Evidence of selection. Heredity, 26, 259-269.

MoffatT, B. 1968. Cat gene frequencies in two Australian cities. 7. Hered., 59, 209-211. ROBINSON, R. 1970. Gene assortment and preferential mating in the breeding of German fancy cats. Heredity, 25, 207-216.

Robinson, R. 1971. Genetics for Cat Breeders. International Series of Monographs in Pure and Applied Biology, Vol. 45. Pergamon Press, Oxford.

Robinson, R. 1972. Mutant gene frequencies in cats of Cyprus. Theoret. Appl. Genetics, $42,293-296$.

ROBINSON, R., AND siLson, M. 1969. Mutant gene frequencies in cats of southern England. Theoret. Appl. Genetics, 39, 326-329.

SEARLE, A. G. 1949. Gene frequencies in London's cats. 7. Genetics, 49, 214-220.

SEARLE, A. G. 1966. Coat colour gene frequencies in Venetian cats. Carnivore Genetics Nerwsl., $1,6-7$.

SNYDER, L. L. 1964. The War: A Concise History 1939-1945. Dell Publishing Co., New York. 
TINNEY, L., AND GRIESEMER, R. A. 1968. Gene frequencies in the cats of Columbus, Ohio, U.S.A., and a comparison of northeast U.S. populations. Carnivore Genetics Neresl., 5, 96-99.

TODD, N. в. 1964a. The Manx factor in domestic cats. 7. Hered., 55, 225-230.

TODD, N. B. 1964b. Gene frequencies in Boston's cats. Heredity, 19, 47-51.

TODD, N. B. 1966. Gene frequencies in the cat population of New York City. 7. Hered., 57, 185-187.

TODD, N. B. 1969. Cat gene frequencies in Chicago and other populations of the United States. 7. Hered., 60, 273-277.

TODD, N. B., ROBINSON, R., AND CLARK, J. M. 1974. Gene frequencies in domestic cats of Greece. 7. Hered., 65, 227-231.

TURNER, P., AND ROBINSON, R. 1973. Heredity of chinchilla, silver and smoke in the cat. Carnivore Genetics Newsl., 2, 121-124. 